\title{
Nutrition and Wound Healing: An Overview Focusing on the Beneficial Effects of Curcumin
}

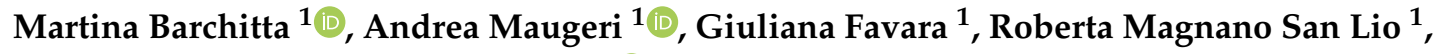 \\ Giuseppe Evola ${ }^{2}$, Antonella Agodi ${ }^{1, *}$ (1) and Guido Basile ${ }^{3}$ \\ 1 Department of Medical and Surgical Sciences and Advanced Technologies "GF Ingrassia", University of \\ Catania, Via S. Sofia 87, 95123 Catania, Italy; martina.barchitta@unict.it (M.B.); \\ andreamaugeri88@gmail.com (A.M.); giuliana.favara@gmail.com (G.F.); robimagnano@gmail.com (R.M.S.L.) \\ 2 General and Emergency Surgery Department, Garibaldi Hospital, Piazza Santa Maria di Gesù, \\ 95100 Catania, Italy; giuseppe_evola@hotmail.it \\ 3 Department of General Surgery and Medical-Surgical Specialties, University of Catania, Via Plebiscito 628, \\ 95124 Catania, Italy; gbasile@unict.it \\ * Correspondence: agodia@unict.it
}

Received: 25 January 2019; Accepted: 1 March 2019; Published: 5 March 2019

\begin{abstract}
Wound healing implicates several biological and molecular events, such as coagulation, inflammation, migration-proliferation, and remodeling. Here, we provide an overview of the effects of malnutrition and specific nutrients on this process, focusing on the beneficial effects of curcumin. We have summarized that protein loss may negatively affect the whole immune process, while adequate intake of carbohydrates is necessary for fibroblast migration during the proliferative phase. Beyond micronutrients, arginine and glutamine, vitamin A, B, C, and D, zinc, and iron are essential for inflammatory process and synthesis of collagen. Notably, anti-inflammatory and antioxidant properties of curcumin might reduce the expression of tumor necrosis factor alpha (TNF- $\alpha$ ) and interleukin-1 (IL-1) and restore the imbalance between reactive oxygen species (ROS) production and antioxidant activity. Since curcumin induces apoptosis of inflammatory cells during the early phase of wound healing, it could also accelerate the healing process by shortening the inflammatory phase. Moreover, curcumin might facilitate collagen synthesis, fibroblasts migration, and differentiation. Although curcumin could be considered as a wound healing agent, especially if topically administered, further research in wound patients is recommended to achieve appropriate nutritional approaches for wound management.
\end{abstract}

Keywords: wound; wound healing; diet; nutrition; micronutrients; macronutrients; curcumin; amino-acids; vitamins; minerals

\section{Introduction}

Wound healing implicates a well-orchestrated complex of biological and molecular events that involve cell migration, cell proliferation, and extracellular matrix deposition. Although these processes are similar to those driving embryogenesis, tissue and organ regeneration, and even pathological conditions [1,2], certain differences exist between adult wounds and these other systems. In acute wounds-cutaneous injuries that do not have an underpinning pathophysiological defect-the main evolutionary force may have been to achieve repair quickly and with the smallest amount of energy [2]. In contrast, evolutionary adaptations have probably not occurred in chronic wounds with pre-existing pathophysiological abnormalities, resulting in impaired healing [3]. Wound care places an enormous drain on healthcare resources worldwide. For instance, in the United States, it has been estimated that $3 \%$ individuals over 65 years will have a wound at any one time [4], with an estimated cost 
to the healthcare system of approximately US $\$ 25$ billion each year [5]. In low-income countries, an even higher incidence, due to traumatic injuries and ulcers, is expected. Recently, the World Health Organization (WHO) has recognized the unmet need for an interdisciplinary approach facing this global challenge, which has been accordingly addressed by the Association for the Advancement of Wound Care (AAWC) Global Volunteers program [6].

Despite strides in technological innovations of a wide range of treatments against wounds, non-healing wounds continue to challenge physicians. Hence, further efforts are needed to improve our scientific understanding of the repair process and how that knowledge can be used to develop new approaches to treatment. Malnutrition is a common risk factor that might contribute to impaired wound healing [7-9]. In recent years, several lines of evidence have pointed out biochemical and molecular effects of several nutrients in the wound healing process, supporting the notion that a complementary nutritional approach might be useful in wound treatment, especially for chronic non-healing wounds [10]. Here, we provide an overview of biological and molecular events in wound healing and the effects of malnutrition and specific nutrients on this process (search strategy and selection criteria are shown in Figure 1). In line with the current Special Issue "Curcumin in Health and Disease", we have also focused on beneficial effects and related molecular mechanisms of curcumin - a natural phenol from the rhizome of Curcuma longa—which might enhance healing processes via antioxidant and anti-inflammatory properties [11]. In fact, curcumin was commonly used in traditional medicine for the treatment of biliary and hepatic disorders, cough, diabetic ulcers, rheumatism and sinusitis [11]. More recently, curcumin has been investigated extensively as an anti-cancer [12], anti-aging [13], and wound healing agent [11]. For instance, it has been demonstrated the beneficial effect of curcumin on the progression of endometriosis, a common disorder affecting women during reproductive age which shares some molecular events with wound healing (i.e., adhesion and proliferation, cellular invasion and angiogenesis) [14]. To date, most of the current knowledge on wound healing derives from in vitro and in vivo studies, while epidemiological investigations are scarce. To solve the question of whether curcumin is a suitable wound healing agent, we have summarized its biochemical and molecular effects during the different phases of wound healing, as well as evidence from epidemiological studies.

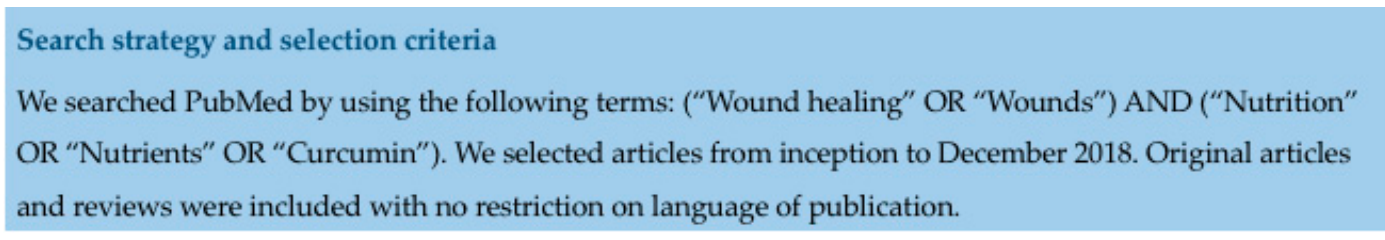

Figure 1. Search strategy and selection criteria.

\subsection{The Wound Healing Process and Impaired Healing}

The type, size, and depth of wounds have significant repercussions on cellular and molecular events that occur after cutaneous injury. As reviewed by Falanga [15], it is useful to divide the wound healing process into four overlapping steps of coagulation, inflammation, migration-proliferation, and remodeling (Figure 2). While acute wounds show a linear progression of these overlapping events, the progression in chronic wounds does not occur in synchrony, with some areas being in different phases at the same time [15]. 


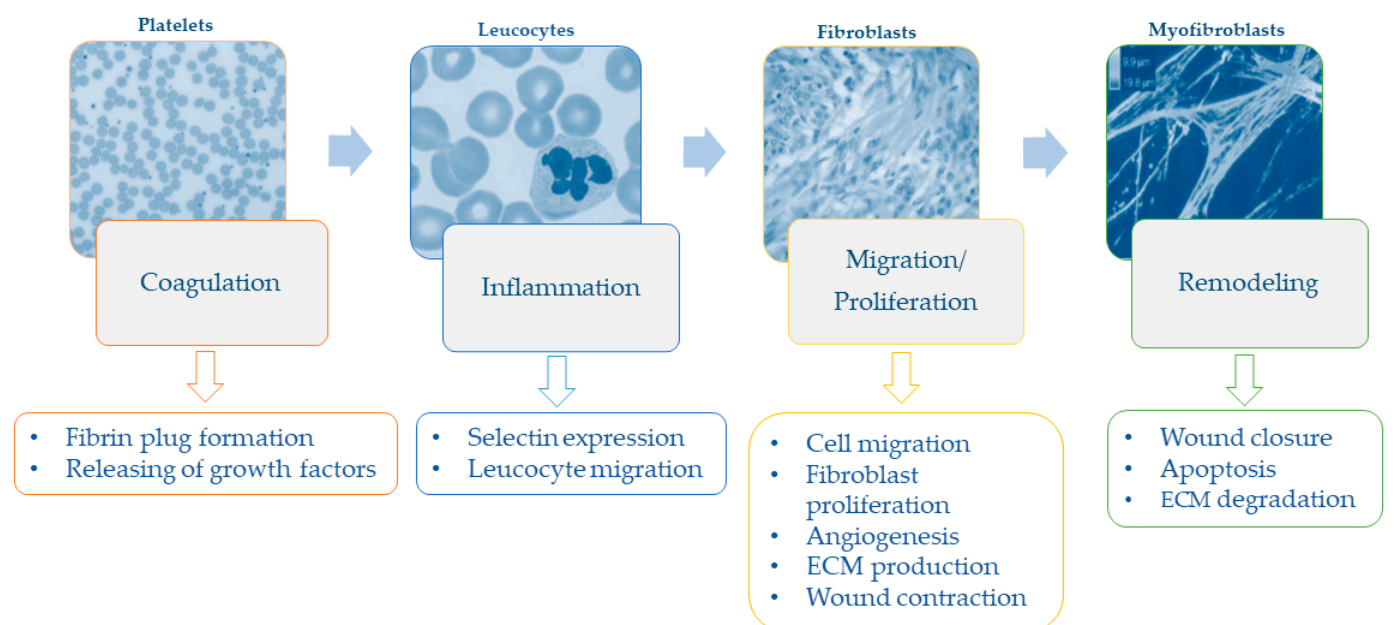

Figure 2. Phases and specific events of the wound healing process.

In the first phase after injury, the formation of a fibrin plug (i.e., an aggregate of platelets, fibrinogen, fibronectin, vitronectin, and thrombospondin) is necessary both for hemostasis and for covering and protecting the wound from bacteria $[2,16]$. Beyond that, fibrin plug also provides an extracellular matrix for cell migration [2] and releases growth factors (e.g., platelet-derived growth factor-PDGF-and transforming growth factor-TGF) involved in the recruitment of cells to the wound $[1,2]$. In the inflammatory phase, endothelial expression of selectins slows down leukocytes in the bloodstream, so as to enable them to move through endothelial gaps by binding to integrins into the extracellular area [1]. Neutrophils and macrophages recruited to the wound remove foreign particles and produce a wide range of growth factors and cytokines that promote fibroblast migration and proliferation [17]. Hypoxia-which occurs immediately after injury-is one of the main triggers of keratinocyte migration, angiogenesis, fibroblast proliferation, and the releasing of growth factors and cytokines (i.e., PDGF, vascular endothelial growth factor, and TGF) [18]. Later, fibroblasts and endothelial cells form the early granulation tissue that begins the processes of wound contraction, which in turn is an efficient driver of wound closure [2]. Extracellular matrix proteins are crucial in this phase because they provide substrates for cell migration and structures that restore the function and integrity of the tissue [18]. The formation of new blood vessels re-establishes tissue perfusion, allowing for the re-supply of oxygen and other nutrients [17]. Finally, once closure of wound has been achieved, remodeling of the resulting scar takes places over weeks or months, with a reduction of both cell content and blood flow, degradation of extracellular matrix, and further contraction and tensile strength [15].

While venous or arterial insufficiency, diabetes, and local-pressure are the most common pathophysiological causes of wounds and ulcers, several local and systemic factors can impair wound healing. The first ones consist of the presence of foreign bodies, tissue maceration, ischemia, and infection. The second ones include aging, malnutrition, diabetes, and renal diseases. In addition to these factors, a reduction in active growth factors may partially explain why certain wounds fail to heal. Chronic ulcers seem to have reduced levels of PDGF, TGF, and other growth factors than acute wounds [19]. Plausible explanations are that growth factors might be trapped by the extracellular matrix [20] or that they might be excessively degraded by proteases [21]. Moreover, in chronic wounds, fibroblasts show a decreased potential of proliferation accompanied by an increased number of senescent cells that might impair responsiveness to growth hormones [22].

\subsection{Malnutrition, Macronutrients, and Chronic Wounds}

According to the WHO, malnutrition refers to all forms of deficiency, excess, or imbalance in a person's intake of energy and/or nutrients [23]. In old people-who are at the highest risk of 
chronic wounds also due to coexisting diseases-malnutrition often consists of either protein-energy malnutrition or specific vitamin and mineral deficiencies [8]. Several age-related conditions increase the risk of developing nutritional deficiencies, such as clinical, physiological, and socio-economic difficulties that usually affect the elderly [8]. Particularly, in diabetic patients, higher glucose levels could interfere with the process of nutrient absorption, causing the depletion of several nutrients (i.e., magnesium, zinc, B12, B6, folic acid) [24]. While the response to an injury may increase the metabolic needs of the wound area, large amounts of protein can be continually lost through wound exudates [25]. Hence, protein and energy requirements of chronic wound patients may rise by $250 \%$ and $50 \%$, respectively [26]. Since cells involved in wound healing require proteins for their formation and activity, protein loss may negatively affect the whole immune process. Proteins are also necessary for immune response, which in turn, if impaired, may delay the progression from the inflammatory to the proliferative phase. In the proliferative and remodeling phases, protein-energy deficiency may also decrease fibroblast activity, delaying angiogenesis and reducing collagen formation [8]. Moreover, protein-calorie deficiency is also associated with weight loss and decreased lean body mass [27]. Hence, implications of weight loss and decreased lean body mass should be recognized when considering the effect of protein-calorie deficiency on the healing process. In general, losing $\approx 10 \%$ lean mass is associated with impaired immunity and increased risk of infection. In case patients lose more than $10 \%$ lean body mass, wound healing competes with body demands to restore lean mass: The metabolism gives priority to healing in patients who lose up to $20 \%$, while it delays healing to restore lean body mass in those who lose more than $30 \%[25,28]$.

Beyond proteins, both carbohydrates and fats address increased energy needs to support inflammatory response, cellular activity, angiogenesis, and collagen deposition in the proliferative phase of healing process [26]. Particularly, adequate intake of carbohydrates is necessary for fibroblast production and movement, and leukocyte activity [29]. Carbohydrates also stimulate secretion of hormones and growth factors, including insulin that is helpful in the anabolic processes of the proliferative phase. In contrast, hyperglycemia and its complications might reduce granulocyte function and promote wound formation [7]. Fats have structural functions in the lipid bilayer of cell membranes during tissue growth. They are also precursors of prostaglandins-which in turn are mediators of cellular inflammation and metabolism — and participate in several signaling pathways [30]. To date, the effect of supplementation of essential fatty acids on wound healing is controversial. While omega-3 supplementation might decrease wound tensile strength with a harmful effect on healing [31], its combination with omega- 6 decreases the progression of pressure ulcers [32]. In line with this evidence, the co-supplementation of omega- 3 and omega- 6 might lead to benefits, especially during the inflammatory phase [33].

\subsection{Micronutrients and Wound Healing}

\subsubsection{Amino-Acids}

Micronutrients involved in the wound healing process have been extensively reviewed [7-9,33]. Among amino-acids, those that play an important role in wound healing, are arginine and glutamine. The first is a precursor of nitric oxide and proline, which in turn are essential for the inflammatory process [34] and synthesis of collagen $[35,36]$. Arginine also stimulates the production and secretion of growth hormone, as well as the activation of T cells [37,38]. In wound patients with adequate protein intake, the recommended dose of arginine supplementation is $4.5 \mathrm{~g} /$ day, while it is useless in the context of protein deficiency [39]. Glutamine plays several roles via its metabolic, enzymatic, antioxidant, and immune properties. In wounds, it protects against the risk of infectious and inflammatory complications by up-regulating the expression of heat shock proteins [40]. Glutamine is also a precursor of glutathione-an antioxidant and an essential cofactor of several enzymatic reactions-which is important for stabilizing cell membranes and for transporting amino acids across them [41]. In addition, glutamine seems involved in the inflammatory phase of wound healing by 
regulating leukocyte apoptosis, superoxide production, antigen processing, and phagocytosis [40,42]. As for arginine, benefits of glutamine supplementation are still controversial [43] and confounded by the combinations of supplements [44].

\subsubsection{Vitamins}

Vitamins are undoubtedly the most investigated micronutrients in the wound healing process. Vitamin A deficiency impairs $\mathrm{B}$ cell and $\mathrm{T}$ cell function and antibody production during the inflammatory phase. It also decreases epithelialization, collagen synthesis, and granulation tissue development in the proliferative and remodeling phases [45]. In addition, vitamin A seems to work as a hormone that modulates the activity of epithelial and endothelial cells, melanocytes, and fibroblasts by binding to retinoic acid receptors [46]. In general, vitamin A is topically administered for the care of dermatologic conditions due to its stimulating properties of fibroplasia and epithelialization [33]. In wound patients, it has been recommended to have a short-term supplementation of 10,000-25,000 IU/day to avoid toxicity [33]. Interestingly, vitamin A supplementation counteracts the delay in wound healing caused by corticosteroids for the treatment of inflammatory diseases [47] by down-regulating TGF- $\beta$ and insulin-like growth factor-1 (IGF-1) [48]. B vitamins, which consist of thiamine, riboflavin, pyridoxine, folic acid, pantothenate, and cobalamins, are essential cofactors in enzyme reactions involved in leukocyte formation and in anabolic processes of wound healing. Among these, thiamine, riboflavin, pyridoxine and cobalamins are also required for the synthesis of collagen [25]. Hence, vitamin B deficiencies indirectly affect the wound healing process by impairing antibody production and white blood cell function, which in turn increase the risk of infectious complications [49]. Vitamin C seems to be involved in wound healing with several roles in cell migration and transformation, collagen synthesis, antioxidant response, and angiogenesis.

In the inflammatory phase, it participates in the recruitment of cells to the wound and their transformation into macrophages [29]. During collagen synthesis, vitamin C forms extra-bounds between collagen fibers that increase stability and strength of collagen matrix [8]. Vitamin C is essential to counteract the production of free radicals in damaged cells, while its deficiency might increase the fragility of new vessels [50]. The current recommendation of vitamin $C$ supplementation ranges from $500 \mathrm{mg} /$ day in non-complicated wounds to $2 \mathrm{~g} /$ day in severe wounds [33]. However, vitamin C supplementation seems to have a beneficial effect only in combination with zinc and arginine, and in pressure ulcer patients [51]. Vitamin D and its receptor (i.e., VDR)—which is ubiquitously expressed in several tissues-modulate structural integrity and transport across epithelial barriers [52]. In line with its roles, recent evidence of vitamin D deficiency among venous and pressure ulcer patients has suggested the potential involvement of vitamin D in the wound healing process [53,54]. However, further research is recommended to understand how vitamin D supplementation might be used in wound care. Although most vitamins show beneficial effects in wound healing, vitamin E might negatively affect collagen synthesis, antioxidant response, and the inflammatory phase [55]. Moreover, vitamin E appears to counteract the benefits of vitamin A supplementation in wound management [56].

\subsubsection{Minerals}

Several minerals are involved in the wound healing process due to their roles as enzyme structural factors, metalloenzymes, and antioxidants. Among these, zinc is essential for DNA replication in cells with high cell division rates, such as inflammatory and epithelial cells, and fibroblasts. In the inflammatory phase, zinc promotes immune response and counteracts susceptibility to infectious complications by activating lymphocytes and producing antibodies [30]. In the proliferative and remodeling phases, it is essential for collagen production, fibroblast proliferation, and epithelialization by stimulating the activity of involved enzymes [8]. Although zinc supplementation of 40-220 mg/day for 10-14 days [57] might be useful in zinc-deficient patients, its benefits in non-deficient patients are currently under debate [9]. Interestingly, topical administration of zinc to surgical wounds significantly improves the healing process [58]. In contrast, conditions that affect zinc metabolism and potential 
drug-nutrient interactions should be considered for the management of wound patients with zinc supplementation [58]. Less evidence exists on the beneficial effects of iron supplementation for promoting wound healing. As iron transports oxygen to the tissues, it is essential for tissue perfusion and collagen synthesis. Hence, iron deficiency results in tissue ischemia, impaired collagen production, and decreased wound strength in the proliferative phase [30].

\subsection{Curcumin and Wound Healing}

In 1910, Milobedzka and colleagues described for the first time the structure of curcumin (Figure 3), one of the three curcuminoids extracted from the powdered rhizome of turmeric plant (Curcuma longa) [59]. More recently, it has been demonstrated that curcumin might modulate physiological and molecular events involved in the inflammatory and proliferative phases of the wound healing process [60].

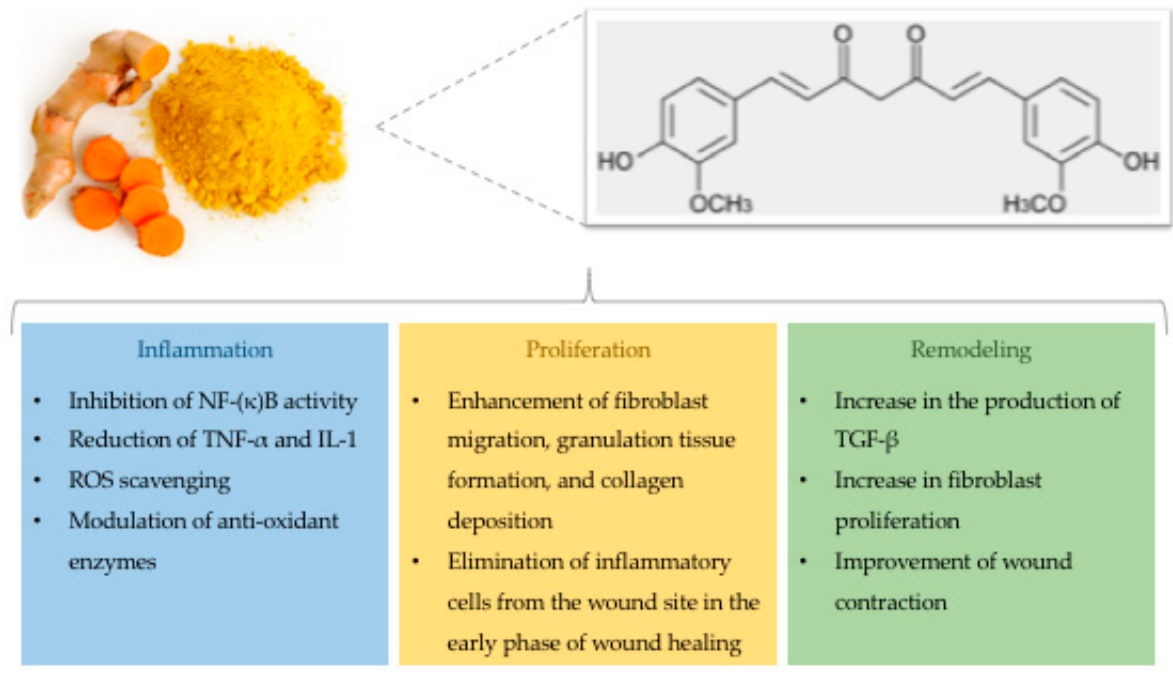

Figure 3. Structure and effects of curcumin on wound healing.

\subsubsection{Effects on the Inflammatory Phase}

With respect to the inflammatory phase, several studies have revealed the protective effect of curcumin that reduces the expression of pro-inflammatory cytokines, such as tumor necrosis factor alpha (TNF- $\alpha$ ) and interleukin-1 (IL-1) [61]. Accordingly, curcumin recruits M2-like macrophages into white adipose tissues, thereby increasing the production of anti-inflammatory cytokines that are essential for the inflammatory response [62]. In addition, curcumin also inhibits nuclear factor $\mathrm{kB}$ (NF-KB) by suppressing the activity of kinases (i.e., AKT, PI3K, IKK) involved in several pathways. In general, NF- $\mathrm{kB}$ is physiologically inactivated by binding to its inhibitor IKB. During inflammation, the up-regulation of inflammatory mediators (i.e., cytokines and chemokines) activates NF- $\mathrm{kB}$, which in turn translocates to the nucleus [63]. In wounded sites, curcumin might reduce inflammation caused by the activation of the NF- $\mathrm{kB}$ pathway [64]. The anti-inflammatory effects of curcumin are also involved in other signaling pathways, such as peroxisome proliferator-activated receptor-gamma (PPAR- $\gamma$ ) and myeloid differentiation protein 2-TLR 4 co-receptor (TLR4-MD2) [65-68]. Li and colleagues have reported that curcumin suppresses proliferation of vascular smooth muscle cells by increasing PPAR- $\gamma$ activity to mitigate angiotensin II-induced inflammatory responses [67]. Additionally, it has been shown that curcumin reduces inflammation through competition with LPS for binding on MD2, thereby inhibiting the TLR4-MD2 signaling complex [68].

Since NF-KB has also several anti-oxidant targets, in 2004, Frey and Malik proposed a relationship between inflammation and oxidation during the wound healing process [69]. In wounds, ROS formation triggers the production and activity of various immune cells (i.e., T lymphocyte subsets, 
macrophages, dendritic cells, B lymphocytes, and natural killer cells). Moreover, prolonged high ROS concentrations are dangerous for cell structures leading to oxidative stress [70,71]. Particularly, hydrogen peroxide $\left(\mathrm{H}_{2} \mathrm{O}_{2}\right)$ and superoxide $\left(\mathrm{O}_{2}{ }^{-}\right)$can be considered as potential markers for the amount of oxidative stress [72]. Although anti-oxidant enzymes (i.e., superoxide dismutase, glutathione peroxidase, and catalase) protect cells against toxic ROS levels [73], the imbalance between ROS concentrations and antioxidant activity could determine chronic diseases. Beyond its anti-inflammatory properties, curcumin also acts as an antioxidant by scavenging ROS, by restoring abnormal changes induced by external factors, and by suppressing transcription factors related to oxidation [74,75]. In vitro and in vivo studies have demonstrated the antioxidant activities of curcumin conferred by its electron-donating groups (i.e., the phenolic hydroxyl group) [76]. Moreover, it contributes to the production and activity of antioxidant enzymes $[77,78]$ and their constituents, such as glutathione (GSH) [79]. In line with these findings, Phan and colleagues have revealed the protective role of curcumin against hydrogen peroxide in keratinocytes and fibroblasts [80].

\subsubsection{Effects on the Proliferative and Remodeling Phases}

As discussed below, curcumin also plays a critical role during the proliferative phase. Interestingly, Gopinath and colleagues have observed that curcumin ameliorates the above-mentioned process, resulting in an increase of hydroxyproline and collagen synthesis [74]. This is consistent with previous studies demonstrating that curcumin decreases the amount of membrane matrix metallo-proteinases (MMPs), which are usually higher in endometriotic mice and human ovarian endometriotic stromal cells. These pathological conditions, in fact, share some molecular events with wound healing, including adhesion and proliferation, cellular invasion, and angiogenesis. Particularly, curcumin could be involved in the process of endometriosis by decreasing the growth and number of endometriotic stromal cells [81]. With respect to wounds, Panchatcharam and colleagues have demonstrated that collagen fibers could mature earlier when wound rats are topically treated with curcumin [70]. Although curcumin does not seem to be involved in the migration of fibroblasts to the wound area in vitro [17], an in vivo study has suggested that curcumin mediates the infiltration of fibroblasts into wound sites, which in turn naturally differentiates into myofibroblasts during the formation of granulation tissue [82]. This controversy might be due to difficulties in creating an in vitro model of fibroblast migration in wounds. Treatment with curcumin also promotes the differentiation of fibroblasts into myofibroblasts [83-86] which marks the beginning of wound contraction [87]. A previous study has also demonstrated that curcumin reduces the epithelialization period of treated wounds if compared with the control group [70]. Finally, once closure of the wound has been achieved, apoptotic processes discard inflammatory cells from wound sites [88-90]. Since curcumin induces apoptosis during the early phase of wound healing, it could also accelerate the healing process by shortening the inflammatory phase [85].

\section{Discussion}

Our review summarizes current evidence about the main biochemical and molecular effects of nutrition, in terms of quality and quantity, on the wound healing process. In line with the Special Issue "Curcumin in Health and Disease", we have focused on the beneficial effects of curcumin, which exerts its anti-inflammatory and antioxidant properties during the different phases of the wound healing process [11]. Several lines of evidence from in vitro and in vivo studies have reported that curcumin might modulate physiological and molecular events during the inflammatory phase $[60,61,65-68,85]$. Moreover, it also exerts antioxidant effects by restoring the imbalance between ROS production and antioxidant activity [74-80]. In the proliferative phase, curcumin might facilitate collagen synthesis [70,74], fibroblasts migration [82], and differentiation [83-86]. In addition, curcumin appears to be beneficial for epithelialization [70] and for apoptotic processes that discard inflammatory cells from the wound site [88-90]. An in vivo study has suggested that curcumin mediates the infiltration of fibroblasts into wound sites, which in turn naturally differentiates into myofibroblasts during 
the formation of granulation tissue [82]. By contrast, curcumin does not seem to be involved in the migration of fibroblasts to the wound area in vitro [17].

This controversy might be due to difficulties in creating an in vitro model of fibroblast migration in wounds. In fact, fibroblast migration depends on several factors that cannot be entirely mimicked with in vitro models, such as cell-environment interactions and homeostatic mechanisms [17]. Recently, in wounds of diabetic rats, it has been demonstrated that topical curcumin treatment enhances angiogenesis, thereby ameliorating the healing process [91]. In line with these findings, curcumin could be considered an interesting phytochemical candidate for the treatment of non-healing wounds. Interestingly, its pleiotropic effect on several signaling pathways-by modulating cellular regulatory systems, such as NF- $\mathrm{kB}$, AKT, growth factors, and Nrf2 transcription factor [92-95]—might be explained by its well-established role in epigenetic mechanisms, such as DNA methylation and histone modification [96]. An understanding of epigenetic regulation in the wound healing process is now becoming an attractive field of research [97], and more efforts should be made to uncover mechanisms underpinning beneficial effects of curcumin and other polyphenols $[96,98]$. As mentioned above, however, most of these findings come from in vitro or in vivo investigations, while evidence from epidemiological studies is scarce. Given its hydrophobicity and extensive first-pass metabolism $[99,100]$, topical administration of curcumin has a greater effect on wound healing than oral administration $[64,88,89]$. Despite strides which have been made in the formulation of curcumin for topical application at the wound site $[74,83-85,101]$, further research is recommended to improve curcumin delivery and to evaluate its effects in wound patients.

Beyond assessing the potential of curcumin as a wound healing agent, we have also indicated that nutritional assessment in patients at risk of chronic wounds could be the first step towards the prevention of non-healing wounds. In fact, these patients often exhibit protein-energy malnutrition or specific vitamin and mineral deficiencies [8]. The wound healing process, for its part, increases the needs of calories and proteins of the wound area, thereby increasing the requirements from chronic wound patients [26]. Given that protein-calorie deficiencies are further associated with weight loss and decreased lean body mass [27], their implications for wound patients should be also recognized. To meet the increased need of energy, especially during the proliferative phase, wounds also metabolize carbohydrates and fats [26], which in turn are necessary for fibroblast and leukocyte activities, secretion of hormones and growth factors, and structural functions [29,30]. Despite this evidence, the effect of macronutrient supplementation is currently controversial, raising the need for further research. For instance, it has been demonstrated that omega-6 supplementation decreases the progression of pressure ulcers [32], and its combination with omega-3 has beneficial effects on the inflammatory phase [33]. However, omega-3 supplementation alone has harmful effects on healing [31].

Beyond macronutrients, several micronutrients play a crucial role in the wound healing process, as extensively reviewed [7-9,33]. Arginine and glutamine exhibit several metabolic, enzymatic, antioxidant, and anti-inflammatory properties that are involved in the inflammatory phase $[34,37,38,40,42]$ and in collagen synthesis [35,36]. However, the beneficial effect of the supplementation of glutamine and arginine, alone or in combination, is still controversial $[43,44]$, probably due to differences in study design, patient characteristics, and type of supplementation. Most of the evidence comes from research on vitamins, with several lines of evidence supporting the benefits of vitamin A $[33,47,48]$, vitamin B [49], vitamin C $[8,29,50]$ and vitamin D $[53,54]$ supplementation. However, to what extent they support wound healing process remains unclear until now. For instance, vitamin $C$ seems to act only in combination with zinc and arginine [51], while vitamin E appears to counteract the benefits of vitamin A [56]. Among minerals, zinc is essential for the inflammatory, proliferative, and remodeling phases by promoting immune response, collagen production, fibroblast proliferation, and epithelialization [8]. Accordingly, topical zinc administration to surgical wounds significantly facilitates wound healing process [58]. These findings cumulatively suggest that nutritional approaches might be useful in the treatment of wounds, especially of chronic non-healing wounds [10]. However, benefits in non-deficient patients are currently under debate [9], 
and further research should take into account conditions that affect nutrient metabolism, such as diabetes and potential nutrient-nutrient interactions [58].

\section{Conclusions}

In conclusion, we support the notion that curcumin could be considered as a wound healing agent, especially if topically administered. However, most of the current knowledge is derived from in vitro and in vivo investigations, while studies in wound patients remain scarce or controversial. Moreover, since nutrition and nutrients in general might affect the wound healing process, nutritional assessment of patients at risk of non-healing wounds could be the first step towards prevention and treatment. However, further research is recommended to develop appropriate nutritional approaches for wound management.

Author Contributions: Conceptualization, A.M., M.B., A.A. and G.B.; methodology, A.M. and M.B.; writing - original draft preparation, A.M., G.F., R.M.S.L., G.E., and A.A.; writing-review and editing, all the authors.

Funding: This research was partially funded by the Department of Medical and Surgical Sciences and Advanced Technologies "GF Ingrassia", University of Catania, Catania, Italy.

Conflicts of Interest: The authors declare no conflict of interest.

\section{Abbreviations}

$\begin{array}{ll}\text { AAWC } & \text { Advancement of Wound Care } \\ \text { GSH } & \text { Glutathione } \\ \mathrm{H}_{2} \mathrm{O}_{2} & \text { Hydrogen Peroxide } \\ \text { IGF-1 } & \text { Insulin-Like Growth Factor-1 } \\ \mathrm{IL-1} & \text { Interleukin-1 } \\ \mathrm{NF}-\mathrm{kB} & \text { Nuclear Factor } \mathrm{kB} \\ \mathrm{O}_{2}^{-} & \text {Hydrogen Superoxide } \\ \text { PDGF } & \text { Platelet-Derived Growth Factor } \\ \text { PPAR- } \gamma & \text { Peroxisome Proliferator-Activated Receptor-Gamma } \\ \text { ROS } & \text { Reactive Oxygen Species } \\ \text { TGF } & \text { Transforming Growth Factor } \\ \text { TLR4-MD2 } & \text { Myeloid Differentiation Protein 2-TLR 4 Co-Receptor } \\ \text { TNF- } \alpha & \text { Tumor Necrosis Factor Alpha } \\ \text { VDR } & \text { Vitamin D Receptor } \\ \text { WHO } & \text { World Health Organization }\end{array}$

\section{References}

1. Martin, P. Wound healing-Aiming for perfect skin regeneration. Science 1997, 276, 75-81. [CrossRef] [PubMed]

2. Singer, A.J.; Clark, R.A. Cutaneous wound healing. N. Engl. J. Med. 1999, 341, 738-746. [CrossRef] [PubMed]

3. Harding, K.G.; Morris, H.L.; Patel, G.K. Science, medicine and the future: Healing chronic wounds. BMJ 2002, 324, 160-163. [CrossRef] [PubMed]

4. Reiber, G.E. Diabetic foot care. Financial implications and practice guidelines. Diabetes Care 1992, 15 (Suppl. 1), 29-31. [CrossRef]

5. Sen, C.K.; Gordillo, G.M.; Roy, S.; Kirsner, R.; Lambert, L.; Hunt, T.K.; Gottrup, F.; Gurtner, G.C.; Longaker, M.T. Human skin wounds: A major and snowballing threat to public health and the economy. Wound Repair Regen. 2009, 17, 763-771. [CrossRef] [PubMed]

6. Serena, T.E. A Global Perspective on Wound Care. Adv. Wound Care (New Rochelle) 2014, 3, 548-552. [CrossRef] [PubMed]

7. Quain, A.M.; Khardori, N.M. Nutrition in Wound Care Management: A Comprehensive Overview. Wounds 2015, 27, 327-335. [PubMed] 
8. Harris, C.L.; Fraser, C. Malnutrition in the institutionalized elderly: The effects on wound healing. Ostomy Wound Manag. 2004, 50, 54-63.

9. Thompson, C.; Fuhrman, M.P. Nutrients and wound healing: Still searching for the magic bullet. Nutr. Clin. Pract. 2005, 20, 331-347. [CrossRef] [PubMed]

10. Enoch, S.; Grey, J.E.; Harding, K.G. ABC of wound healing. Non-surgical and drug treatments. BMJ 2006, 332, 900-903. [CrossRef] [PubMed]

11. Akbik, D.; Ghadiri, M.; Chrzanowski, W.; Rohanizadeh, R. Curcumin as a wound healing agent. Life Sci. 2014, 116, 1-7. [CrossRef] [PubMed]

12. Agrawal, D.K.; Mishra, P.K. Curcumin and its analogues: Potential anticancer agents. Med. Res. Rev. 2010, 30, 818-860. [CrossRef] [PubMed]

13. Lima, C.F.; Pereira-Wilson, C.; Rattan, S.I. Curcumin induces heme oxygenase-1 in normal human skin fibroblasts through redox signaling: Relevance for anti-aging intervention. Mol. Nutr. Food Res. 2011, 55, 430-442. [CrossRef] [PubMed]

14. Arablou, T.; Kolahdouz-Mohammadi, R. Curcumin and endometriosis: Review on potential roles and molecular mechanisms. Biomed. Pharmacother. 2018, 97, 91-97. [CrossRef] [PubMed]

15. Falanga, V. Wound healing and its impairment in the diabetic foot. Lancet 2005, 366, 1736-1743. [CrossRef]

16. Velnar, T.; Bailey, T.; Smrkolj, V. The wound healing process: An overview of the cellular and molecular mechanisms. J. Int. Med. Res. 2009, 37, 1528-1542. [CrossRef] [PubMed]

17. Topman, G.; Lin, F.H.; Gefen, A. The natural medications for wound healing-Curcumin, Aloe-Vera and Ginger-Do not induce a significant effect on the migration kinematics of cultured fibroblasts. J. Biomech. 2013, 46, 170-174. [CrossRef] [PubMed]

18. Falanga, V. The chronic wound: Impaired healing and solutions in the context of wound bed preparation. Blood Cells Mol. Dis. 2004, 32, 88-94. [CrossRef] [PubMed]

19. Santoro, M.M.; Gaudino, G. Cellular and molecular facets of keratinocyte reepithelization during wound healing. Exp. Cell Res. 2005, 304, 274-286. [CrossRef] [PubMed]

20. Iyer, V.; Pumiglia, K.; DiPersio, C.M. Alpha3beta1 integrin regulates MMP-9 mRNA stability in immortalized keratinocytes: A novel mechanism of integrin-mediated MMP gene expression. J. Cell Sci. 2005, 118, 1185-1195. [CrossRef] [PubMed]

21. Choma, D.P.; Pumiglia, K.; DiPersio, C.M. Integrin alpha3beta1 directs the stabilization of a polarized lamellipodium in epithelial cells through activation of Rac1. J. Cell Sci. 2004, 117, 3947-3959. [CrossRef] [PubMed]

22. Nahm, W.K.; Philpot, B.D.; Adams, M.M.; Badiavas, E.V.; Zhou, L.H.; Butmarc, J.; Bear, M.F.; Falanga, V. Significance of N-methyl-D-aspartate (NMDA) receptor-mediated signaling in human keratinocytes. J. Cell. Physiol. 2004, 200, 309-317. [CrossRef] [PubMed]

23. Malnutrition. Available online: https://www.who.int/en/news-room/fact-sheets/detail/malnutrition (accessed on 1 January 2019).

24. Katsarou, A.; Gudbjörnsdottir, S.; Rawshani, A.; Dabelea, D.; Bonifacio, E.; Anderson, B.J.; Jacobsen, L.M.; Schatz, D.A.; Lernmark, Å. Type 1 diabetes mellitus. Nat. Rev. Dis. Primers 2017, 3, 17016. [CrossRef] [PubMed]

25. Russell, L. The importance of patients' nutritional status in wound healing. Br. J. Nurs. 2001, 10, S42-S49. [CrossRef] [PubMed]

26. Breslow, R.A.; Hallfrisch, J.; Guy, D.G.; Crawley, B.; Goldberg, A.P. The importance of dietary protein in healing pressure ulcers. J. Am. Geriatr. Soc. 1993, 41, 357-362. [CrossRef] [PubMed]

27. Chen, C.C.; Schilling, L.S.; Lyder, C.H. A concept analysis of malnutrition in the elderly. J. Adv. Nurs. 2001, 36, 131-142. [CrossRef] [PubMed]

28. Evans, C. Malnutrition in the elderly: A multifactorial failure to thrive. Perm. J. 2005, 9, 38-41. [CrossRef] [PubMed]

29. Casey, G. Nutritional support in wound healing. Nurs. Stand. 2003, 17, 55-58. [CrossRef] [PubMed]

30. Todorovic, V. Food and wounds: Nutritional factors in wound formation and healing. Br. J. Community Nurs. 2002, 7, 43-54. [CrossRef]

31. Albina, J.E.; Gladden, P.; Walsh, W.R. Detrimental effects of an omega-3 fatty acid-enriched diet on wound healing. JPEN J. Parenter. Enter. Nutr. 1993, 17, 519-521. [CrossRef] [PubMed] 
32. Theilla, M.; Schwartz, B.; Cohen, J.; Shapiro, H.; Anbar, R.; Singer, P. Impact of a nutritional formula enriched in fish oil and micronutrients on pressure ulcers in critical care patients. Am. J. Crit. Care 2012, 21, e102-e109. [CrossRef] [PubMed]

33. Molnar, J.A.; Underdown, M.J.; Clark, W.A. Nutrition and Chronic Wounds. Adv. Wound Care (New Rochelle) 2014, 3, 663-681. [CrossRef] [PubMed]

34. Debats, I.B.; Wolfs, T.G.; Gotoh, T.; Cleutjens, J.P.; Peutz-Kootstra, C.J.; van der Hulst, R.R. Role of arginine in superficial wound healing in man. Nitric Oxide 2009, 21, 175-183. [CrossRef] [PubMed]

35. Schäffer, M.R.; Tantry, U.; Thornton, F.J.; Barbul, A. Inhibition of nitric oxide synthesis in wounds: Pharmacology and effect on accumulation of collagen in wounds in mice. Eur. J. Surg. 1999, 165, 262-267. [CrossRef] [PubMed]

36. Kirk, S.J.; Hurson, M.; Regan, M.C.; Holt, D.R.; Wasserkrug, H.L.; Barbul, A. Arginine stimulates wound healing and immune function in elderly human beings. Surgery 1993, 114, 155-159; discussion 160. [PubMed]

37. Wu, G.; Bazer, F.W.; Davis, T.A.; Kim, S.W.; Li, P.; Marc Rhoads, J.; Carey Satterfield, M.; Smith, S.B.; Spencer, T.E.; Yin, Y. Arginine metabolism and nutrition in growth, health and disease. Amino Acids 2009, 37, 153-168. [CrossRef] [PubMed]

38. Barbul, A. Proline precursors to sustain Mammalian collagen synthesis. J. Nutr. 2008, 138, 2021S-2024S. [CrossRef] [PubMed]

39. Leigh, B.; Desneves, K.; Rafferty, J.; Pearce, L.; King, S.; Woodward, M.C.; Brown, D.; Martin, R.; Crowe, T.C. The effect of different doses of an arginine-containing supplement on the healing of pressure ulcers. J. Wound Care 2012, 21, 150-156. [CrossRef] [PubMed]

40. Wischmeyer, P.E. Glutamine and heat shock protein expression. Nutrition 2002, 18, 225-228. [CrossRef]

41. Newsholme, P. Why is L-glutamine metabolism important to cells of the immune system in health, postinjury, surgery or infection? J. Nutr. 2001, 131, 2515S-2522S; discussion 2523S-2514S. [CrossRef] [PubMed]

42. Ardawi, M.S. Glutamine and glucose metabolism in human peripheral lymphocytes. Metabolism 1988, 37, 99-103. [CrossRef]

43. Peng, X.; Yan, H.; You, Z.; Wang, P.; Wang, S. Clinical and protein metabolic efficacy of glutamine granules-supplemented enteral nutrition in severely burned patients. Burns 2005, 31, 342-346. [CrossRef] [PubMed]

44. Blass, S.C.; Goost, H.; Tolba, R.H.; Stoffel-Wagner, B.; Kabir, K.; Burger, C.; Stehle, P.; Ellinger, S. Time to wound closure in trauma patients with disorders in wound healing is shortened by supplements containing antioxidant micronutrients and glutamine: A PRCT. Clin. Nutr. 2012, 31, 469-475. [CrossRef] [PubMed]

45. Stadelmann, W.K.; Digenis, A.G.; Tobin, G.R. Impediments to wound healing. Am. J. Surg. 1998, 176, 39S-47S. [CrossRef]

46. Reichrath, J.; Lehmann, B.; Carlberg, C.; Varani, J.; Zouboulis, C.C. Vitamins as hormones. Horm. Metab. Res. 2007, 39, 71-84. [CrossRef] [PubMed]

47. Hunt, T.K.; Ehrlich, H.P.; Garcia, J.A.; Dunphy, J.E. Effect of vitamin A on reversing the inhibitory effect of cortisone on healing of open wounds in animals and man. Ann. Surg. 1969, 170, 633-641. [CrossRef] [PubMed]

48. Wicke, C.; Halliday, B.; Allen, D.; Roche, N.S.; Scheuenstuhl, H.; Spencer, M.M.; Roberts, A.B.; Hunt, T.K. Effects of steroids and retinoids on wound healing. Arch. Surg. 2000, 135, 1265-1270. [CrossRef] [PubMed]

49. Williams, J.Z.; Barbul, A. Nutrition and wound healing. Crit. Care Nurs. Clin. N. Am. 2012, 24, 179-200. [CrossRef] [PubMed]

50. Shepherd, A.A. Nutrition for optimum wound healing. Nurs. Stand. 2003, 18, 55-58. [PubMed]

51. Ellinger, S.; Stehle, P. Efficacy of vitamin supplementation in situations with wound healing disorders: Results from clinical intervention studies. Curr. Opin. Clin. Nutr. Metab. Care 2009, 12, 588-595. [CrossRef] [PubMed]

52. Zhang, Y.G.; Wu, S.; Sun, J. Vitamin D, Vitamin D Receptor, and Tissue Barriers. Tissue Barriers 2013, 1, e23118. [CrossRef] [PubMed]

53. Burkievcz, C.J.; Skare, T.L.; Malafaia, O.; Nassif, P.A.; Ribas, C.S.; Santos, L.R. Vitamin D deficiency in patients with chronic venous ulcers. Rev. Col. Bras. Cir. 2012, 39, 60-63. [CrossRef] [PubMed]

54. Kalava, U.R.; Cha, S.S.; Takahashi, P.Y. Association between vitamin D and pressure ulcers in older ambulatory adults: Results of a matched case-control study. Clin. Interv. Aging 2011, 6, 213-219. [CrossRef] [PubMed] 
55. Mazzotta, M.Y. Nutrition and wound healing. J. Am. Podiatr. Med. Assoc. 1994, 84, 456-462. [CrossRef] [PubMed]

56. Trujillo, E.B. Effects of nutritional status on wound healing. J. Vasc. Nurs. 1993, 11, 12-18. [PubMed]

57. Fosmire, G.J. Zinc toxicity. Am. J. Clin. Nutr. 1990, 51, 225-227. [CrossRef] [PubMed]

58. Lansdown, A.B.; Mirastschijski, U.; Stubbs, N.; Scanlon, E.; Agren, M.S. Zinc in wound healing: Theoretical, experimental, and clinical aspects. Wound Repair Regen. 2007, 15, 2-16. [CrossRef] [PubMed]

59. Milobedzka, J.; Kostanecki, S.; Lampe, V. Zur Kenntnis des Curcumins. Ber. Dtsch. Chem. Ges. 1910, 43, 2163-2170. [CrossRef]

60. Bielefeld, K.A.; Amini-Nik, S.; Alman, B.A. Cutaneous wound healing: recruiting developmental pathways for regeneration. Cell. Mol. Life Sci. 2013, 70, 2059-2081. [CrossRef] [PubMed]

61. Wu, N.C.; Wang, J.J. Curcumin attenuates liver warm ischemia and reperfusion-induced combined restrictive and obstructive lung disease by reducing matrix metalloprotease 9 activity. Transplant. Proc. 2014, 46, 1135-1138. [CrossRef] [PubMed]

62. Song, Z.; Revelo, X.; Shao, W.; Tian, L.; Zeng, K.; Lei, H.; Sun, H.S.; Woo, M.; Winer, D.; Jin, T. Dietary Curcumin Intervention Targets Mouse White Adipose Tissue Inflammation and Brown Adipose Tissue UCP1 Expression. Obesity (Silver Spring) 2018, 26, 547-558. [CrossRef] [PubMed]

63. Hunter, C.J.; De Plaen, I.G. Inflammatory signaling in NEC: Role of NF-kB, cytokines and other inflammatory mediators. Pathophysiology 2014, 21, 55-65. [CrossRef] [PubMed]

64. Merrell, J.G.; McLaughlin, S.W.; Tie, L.; Laurencin, C.T.; Chen, A.F.; Nair, L.S. Curcumin-loaded poly(epsilon-caprolactone) nanofibres: Diabetic wound dressing with anti-oxidant and anti-inflammatory properties. Clin. Exp. Pharmacol. Physiol. 2009, 36, 1149-1156. [CrossRef] [PubMed]

65. Wang, J.; Wang, H.; Zhu, R.; Liu, Q.; Fei, J.; Wang, S. Anti-inflammatory activity of curcumin-loaded solid lipid nanoparticles in $I L-1 \beta$ transgenic mice subjected to the lipopolysaccharide-induced sepsis. Biomaterials 2015, 53, 475-483. [CrossRef] [PubMed]

66. Antoine, F.; Girard, D. Curcumin increases gelatinase activity in human neutrophils by a p38 mitogen-activated protein kinase (MAPK)-independent mechanism. J. Immunotoxicol. 2015, 12, 188-193. [CrossRef] [PubMed]

67. Li, H.Y.; Yang, M.; Li, Z.; Meng, Z. Curcumin inhibits angiotensin II-induced inflammation and proliferation of rat vascular smooth muscle cells by elevating PPAR- $\gamma$ activity and reducing oxidative stress. Int. J. Mol. Med. 2017, 39, 1307-1316. [CrossRef] [PubMed]

68. Zhang, Y.; Liu, Z.; Wu, J.; Bai, B.; Chen, H.; Xiao, Z.; Chen, L.; Zhao, Y.; Lum, H.; Wang, Y.; et al. New MD2 inhibitors derived from curcumin with improved anti-inflammatory activity. Eur. J. Med. Chem. 2018, 148, 291-305. [CrossRef] [PubMed]

69. Frey, R.S.; Malik, A.B. Oxidant signaling in lung cells. Am. J. Physiol. Lung Cell. Mol. Physiol. 2004, 286, L1-L3. [CrossRef] [PubMed]

70. Panchatcharam, M.; Miriyala, S.; Gayathri, V.S.; Suguna, L. Curcumin improves wound healing by modulating collagen and decreasing reactive oxygen species. Mol. Cell. Biochem. 2006, 290, 87-96. [CrossRef] [PubMed]

71. Roy, S.; Khanna, S.; Nallu, K.; Hunt, T.K.; Sen, C.K. Dermal wound healing is subject to redox control. Mol. Ther. 2006, 13, 211-220. [CrossRef] [PubMed]

72. Imlay, J.A. Pathways of oxidative damage. Annu. Rev. Microbiol. 2003, 57, 395-418. [CrossRef] [PubMed]

73. Matés, J.M.; Segura, J.A.; Alonso, F.J.; Márquez, J. Roles of dioxins and heavy metals in cancer and neurological diseases using ROS-mediated mechanisms. Free Radic. Biol. Med. 2010, 49, 1328-1341. [CrossRef] [PubMed]

74. Gopinath, D.; Ahmed, M.R.; Gomathi, K.; Chitra, K.; Sehgal, P.K.; Jayakumar, R. Dermal wound healing processes with curcumin incorporated collagen films. Biomaterials 2004, 25, 1911-1917. [CrossRef]

75. Tapia, E.; Sánchez-Lozada, L.G.; García-Niño, W.R.; García, E.; Cerecedo, A.; García-Arroyo, F.E.; Osorio, H.; Arellano, A.; Cristóbal-García, M.; Loredo, M.L.; et al. Curcumin prevents maleate-induced nephrotoxicity: Relation to hemodynamic alterations, oxidative stress, mitochondrial oxygen consumption and activity of respiratory complex I. Free Radic. Res. 2014, 48, 1342-1354. [CrossRef] [PubMed]

76. Zheng, Q.T.; Yang, Z.H.; Yu, L.Y.; Ren, Y.Y.; Huang, Q.X.; Liu, Q.; Ma, X.Y.; Chen, Z.K.; Wang, Z.B.; Zheng, X. Synthesis and antioxidant activity of curcumin analogs. J. Asian Nat. Prod. Res. 2017, 19, 489-503. [CrossRef] [PubMed] 
77. Reddy, A.C.; Lokesh, B.R. Effect of dietary turmeric (Curcuma longa) on iron-induced lipid peroxidation in the rat liver. Food Chem. Toxicol. 1994, 32, 279-283. [CrossRef]

78. Subudhi, U.; Chainy, G.B. Expression of hepatic antioxidant genes in 1-thyroxine-induced hyperthyroid rats: Regulation by vitamin E and curcumin. Chem. Biol. Interact. 2010, 183, 304-316. [CrossRef] [PubMed]

79. Dai, C.; Tang, S.; Li, D.; Zhao, K.; Xiao, X. Curcumin attenuates quinocetone-induced oxidative stress and genotoxicity in human hepatocyte L02 cells. Toxicol. Mech. Methods 2015, 25, 340-346. [CrossRef] [PubMed]

80. Phan, T.T.; See, P.; Lee, S.T.; Chan, S.Y. Protective effects of curcumin against oxidative damage on skin cells in vitro: Its implication for wound healing. J. Trauma 2001, 51, 927-931. [CrossRef] [PubMed]

81. Zhang, Y.; Cao, H.; Yu, Z.; Peng, H.Y.; Zhang, C.J. Curcumin inhibits endometriosis endometrial cells by reducing estradiol production. Iran. J. Reprod. Med. 2013, 11, 415-422. [PubMed]

82. Petroll, W.M.; Cavanagh, H.D.; Barry, P.; Andrews, P.; Jester, J.V. Quantitative analysis of stress fiber orientation during corneal wound contraction. J. Cell Sci. 1993, 104 Pt 2, 353-363.

83. Durgaprasad, S.; Reetesh, R.; Hareesh, K.; Rajput, R. Effect of topical curcumin preparation (BIOCURCUMAX) on burn wound healing in rats. J. Pharm. Biomed. Sci. (JPBMS) 2011, 8, 1-3.

84. Dai, M.; Zheng, X.; Xu, X.; Kong, X.; Li, X.; Guo, G.; Luo, F.; Zhao, X.; Wei, Y.Q.; Qian, Z. Chitosan-alginate sponge: Preparation and application in curcumin delivery for dermal wound healing in rat. J. Biomed. Biotechnol. 2009, 2009, 595126. [CrossRef] [PubMed]

85. Mohanty, C.; Das, M.; Sahoo, S.K. Sustained wound healing activity of curcumin loaded oleic acid based polymeric bandage in a rat model. Mol. Pharm. 2012, 9, 2801-2811. [CrossRef] [PubMed]

86. Jagetia, G.C.; Rajanikant, G.K. Acceleration of wound repair by curcumin in the excision wound of mice exposed to different doses of fractionated $\gamma$ radiation. Int. Wound J. 2012, 9, 76-92. [CrossRef] [PubMed]

87. Welch, M.P.; Odland, G.F.; Clark, R.A. Temporal relationships of F-actin bundle formation, collagen and fibronectin matrix assembly, and fibronectin receptor expression to wound contraction. J. Cell Biol. 1990, 110, 133-145. [CrossRef] [PubMed]

88. Sidhu, G.S.; Singh, A.K.; Thaloor, D.; Banaudha, K.K.; Patnaik, G.K.; Srimal, R.C.; Maheshwari, R.K. Enhancement of wound healing by curcumin in animals. Wound Repair Regen. 1998, 6, 167-177. [CrossRef] [PubMed]

89. Sidhu, G.S.; Mani, H.; Gaddipati, J.P.; Singh, A.K.; Seth, P.; Banaudha, K.K.; Patnaik, G.K.; Maheshwari, R.K. Curcumin enhances wound healing in streptozotocin induced diabetic rats and genetically diabetic mice. Wound Repair Regen. 1999, 7, 362-374. [CrossRef] [PubMed]

90. Brown, D.L.; Kao, W.W.; Greenhalgh, D.G. Apoptosis down-regulates inflammation under the advancing epithelial wound edge: Delayed patterns in diabetes and improvement with topical growth factors. Surgery 1997, 121, 372-380. [CrossRef]

91. Kant, V.; Gopal, A.; Kumar, D.; Pathak, N.N.; Ram, M.; Jangir, B.L.; Tandan, S.K. Curcumin-induced angiogenesis hastens wound healing in diabetic rats. J. Surg. Res. 2015, 193, 978-988. [CrossRef] [PubMed]

92. Abe, Y.; Hashimoto, S.; Horie, T. Curcumin inhibition of inflammatory cytokine production by human peripheral blood monocytes and alveolar macrophages. Pharmacol. Res. 1999, 39, 41-47. [CrossRef] [PubMed]

93. Balogun, E.; Hoque, M.; Gong, P.; Killeen, E.; Green, C.J.; Foresti, R.; Alam, J.; Motterlini, R. Curcumin activates the haem oxygenase-1 gene via regulation of Nrf2 and the antioxidant-responsive element. Biochem. J. 2003, 371, 887-895. [CrossRef] [PubMed]

94. Huang, M.T.; Lysz, T.; Ferraro, T.; Abidi, T.F.; Laskin, J.D.; Conney, A.H. Inhibitory effects of curcumin on in vitro lipoxygenase and cyclooxygenase activities in mouse epidermis. Cancer Res. 1991, 51, 813-819. [PubMed]

95. Woo, J.H.; Kim, Y.H.; Choi, Y.J.; Kim, D.G.; Lee, K.S.; Bae, J.H.; Min, D.S.; Chang, J.S.; Jeong, Y.J.; Lee, Y.H.; et al. Molecular mechanisms of curcumin-induced cytotoxicity: Induction of apoptosis through generation of reactive oxygen species, down-regulation of $B c l-X L$ and $I A P$, the release of cytochrome $\mathrm{c}$ and inhibition of Akt. Carcinogenesis 2003, 24, 1199-1208. [CrossRef] [PubMed]

96. Maugeri, A.; Mazzone, M.G.; Giuliano, F.; Vinciguerra, M.; Basile, G.; Barchitta, M.; Agodi, A. Curcumin Modulates DNA Methyltransferase Functions in a Cellular Model of Diabetic Retinopathy. Oxid. Med. Cell. Longev. 2018, 2018, 5407482. [CrossRef] [PubMed]

97. Lewis, C.J.; Mardaryev, A.N.; Sharov, A.A.; Fessing, M.Y.; Botchkarev, V.A. The Epigenetic Regulation of Wound Healing. Adv. Wound Care (New Rochelle) 2014, 3, 468-475. [CrossRef] [PubMed] 
98. Maugeri, A.; Barchitta, M.; Mazzone, M.G.; Giuliano, F.; Basile, G.; Agodi, A. Resveratrol modulates SIRT1 and DNMT functions and restores LINE-1 methylation levels in ARPE-19 cells under oxidative stress and inflammation. Int. J. Mol. Sci. 2018, 19, 2118. [CrossRef] [PubMed]

99. Ravindranath, V.; Chandrasekhara, N. Absorption and tissue distribution of curcumin in rats. Toxicology 1980, 16, 259-265. [CrossRef]

100. Asai, A.; Miyazawa, T. Occurrence of orally administered curcuminoid as glucuronide and glucuronide/sulfate conjugates in rat plasma. Life Sci. 2000, 67, 2785-2793. [CrossRef]

101. Hegge, A.B.; Andersen, T.; Melvik, J.E.; Bruzell, E.; Kristensen, S.; Tønnesen, H.H. Formulation and bacterial phototoxicity of curcumin loaded alginate foams for wound treatment applications: Studies on curcumin and curcuminoides XLII. J. Pharm. Sci. 2011, 100, 174-185. [CrossRef] [PubMed]

(C) 2019 by the authors. Licensee MDPI, Basel, Switzerland. This article is an open access article distributed under the terms and conditions of the Creative Commons Attribution (CC BY) license (http:/ / creativecommons.org/licenses/by/4.0/). 